\title{
Accuracy of Oxygen and Carbon Dioxide Electrodes
}

\author{
D. C. FLENLEY,* M.B., B.SC., M.R.C.P., M.R.C.P.ED. ; J. S. MILLAR, $\dagger$ M.B., M.R.C.P.GLASG., M.R.C.P.ED. \\ H. A. REES, $\ddagger$ M.B., B.SC., M.R.C.P.
}

Brit. med. F., 1967, 2, 349-352

Direct determinations of the oxygen tension $\left(\mathrm{Po}_{2}\right)$ and carbon dioxide tension $\left(\mathrm{PCO}_{2}\right)$ of arterial blood are now widely used in the diagnosis and management of diseases of the heart and lungs. Commercial electrode systems, based on the Clark oxygen cell (Clark, 1956), and the Severinghaus $\mathrm{PcO}_{2}$ electrode (Severinghaus and Bradley, 1958) are expensive items, and it is important to know the accuracy of these commercial instruments. This report describes the performance of two commercial electrode systems, the Radiometer $\mathrm{Co}$. $\mathrm{Po}_{2}$ electrode type E 5044 and $\mathrm{PCO}_{2}$ electrode type E 5030, and the Instrumentation Laboratories Inc. combined $\mathrm{Po}_{2}, \mathrm{PCO}_{2}$, and $\mathrm{pH}$ electrode system type 113-S1, when used to measure the $\mathrm{Po}_{2}$ of gas mixtures and blood samples and the $\mathrm{PCO}_{2}$ of blood samples. Both these oxygen electrodes are of the modern microcathode type, in which the blood samples are not stirred in the cuvettes. The performance of the instruments was studied over the range 0-200 mm. $\mathrm{Hg}$ for $\mathrm{Po}_{2}$ and $20-100 \mathrm{~mm}$. $\mathrm{Hg}$ for $\mathrm{PCO}_{2}$, as this represented the range most commonly encountered in clinical work.

\section{Methods}

A new tonometer system, based on the rotating disc principle of the Melrose oxygenator (Flenley and Millar, 1967) was used to prepare blood samples of known $\mathrm{Po}_{2}$ and $\mathrm{PCO}_{2}$, by mixing blood with gas mixtures at $37^{\circ} \mathrm{C}$. The tonometer was assessed for efficiency of oxygen transport by calculation of its diffusing capacity, the rate of equilibration, the amount of haemolysis produced, and for the effect of bacterial contamination on the results. The tonometer uses a continually flowing stream of gas, the mixtures being prepared in Douglas bags by the rotameter mixing device of Flenley (1964). Samples of gas for Lloyd-Haldane analyses (duplicate analyses within $0.03 \%$ ) were taken from the gas stream as it left the tonometer. Freshly drawn heparinized human blood was used in the tonometer, samples being transferred to the electrode cuvettes in siliconed glass syringes, after equilibration with the gas mixtures had occurred.

The $\mathrm{PO}_{2}$ electrodes were set up with " white spot" nitrogen as the low reference point, and humidified air, or blood tonometered with air, as the high reference point. Air and nitrogen were introduced by $50-\mathrm{ml}$. syringes and the meter settings made when the readings were steady, between three and five minutes later. When the oxygen electrodes were used to measure the $\mathrm{Po}_{\text {, }}$ of gas mixtures the samples were also introduced from $50-\mathrm{ml}$. syringes. These gas mixtures, consisting of nitrogen, oxygen, and carbon dioxide, were analysed by the Lloyd-Haldane apparatus. The $\mathrm{PCO}_{2}$ electrodes were set up with mixtures of approximately $3 \% \mathrm{CO}_{2}$ in $17 \% \mathrm{O}_{2}$ and $9 \% \mathrm{CO}_{2}$ in $17 \%$ $\mathrm{O}_{2}$, the actual concentrations being determined by LloydHaldane analysis of the compressed gas mixtures. These reference gases were flushed through the cuvettes of the $\mathrm{CO}_{2}$ electrodes at $25 \mathrm{ml} . / \mathrm{min}$. for at least $10 \mathrm{minutes,} \mathrm{all} \mathrm{gas}$ connexions being by thick-wall rubber tubing. Final meter

\footnotetext{
* Lecturer in Medicine.

$\dagger$ Medical Research Council Scientific Assistant.

\$Senior Medical Registrar.

Department of Medicine, University of Edinburgh, at the Royal Infirm ary, Edinburgh 3.
}

settings were made with zero gas flow for both $\mathrm{Po}_{2}$ and $\mathrm{PcO}_{2}$ electrodes.

The electrode solutions, membranes, and setting-up procedure were exactly as described by the manufacturers. The membranes were polypropylene for the $\mathrm{Po}_{2}$ electrodes and Teflon for the $\mathrm{PCO}_{2}$ electrodes. Before each reading of tonometered blood the $\mathrm{PO}_{2}$ electrodes were flushed with nitrogen, air, and finally tonometer gas, which immediately preceded the sample of tonometer blood. The $\mathrm{PCO}_{2}$ electrodes were flushed with tonometer gas before each blood sample. The electrode cuvettes were filled with $1: 1,000$ solution of Roccal (benzalkonium chloride) overnight.

\section{Results}

The results of the calibration experiments are shown in Figs. 1 to 4 . The regression equations describing the relation between tonometer gas $\mathrm{PO}_{2}$ (or $\mathrm{PCO}_{2}$ ) and the electrode reading of $\mathrm{Po}_{2}$ (or $\mathrm{PCO}_{2}$ ) are calculated in the form:

Electrode $\mathrm{PO}_{2}\left(\right.$ or $\left.\mathrm{PCO}_{2}\right)=\mathrm{A}+\mathrm{B}\left(\right.$ tonometer gas $\mathrm{Po}_{2}\left(\right.$ or $\left.\mathrm{PcO}_{2}\right)$ ).

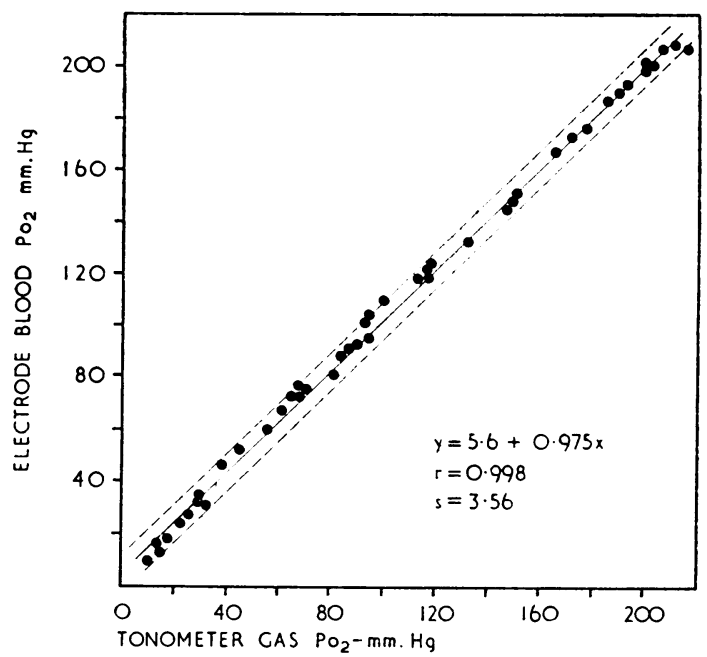

FIG 1.-Radiometer $\mathrm{Po}_{2}$ electrode, set up with nitrogen and blood tonometered with air. One reading on each sample. Broken lines at $95 \%$ confidence limits.

\begin{tabular}{|c|c|c|c|c|c|c|}
\hline Electrode & $\begin{array}{c}\text { Reference } \\
\text { Points }\end{array}$ & $\begin{array}{l}\text { No. of } \\
\text { Obser- } \\
\text { vations }\end{array}$ & Medium & $\begin{array}{l}\text { Coefficient } \\
\text { (B) }\end{array}$ & $\begin{array}{c}\text { Intercept } \\
\text { (A) }\end{array}$ & S.D. \\
\hline \multicolumn{7}{|c|}{ A. Oxygen electrodes (range $0-200 \mathrm{~mm} . \mathrm{Hg}$ ) } \\
\hline $\begin{array}{l}\text { Radio- } \\
\text { meter } \\
\text { E5044 }\end{array}$ & $\begin{array}{l}\text { Nitrogen. Air } \\
\text { Nitrogen. Tono- } \\
\text { metered blood }\end{array}$ & $\begin{array}{l}87 \\
46 \\
46\end{array}$ & $\begin{array}{l}\text { Gas } \\
\text { Blood } \\
\text { ” }\end{array}$ & $\begin{array}{l}1.002 \\
0.90 \\
0.98\end{array}$ & $\begin{array}{r}-0.5 \\
7.4 \\
5.6\end{array}$ & $\begin{array}{l}1.8 \\
3.6 \\
2.6\end{array}$ \\
\hline I.L. $\mathrm{Po}_{2}$ & $\begin{array}{l}\text { Nitrogen. Air } \\
\text { N" } \\
\text { Nitrogen. Tono- } \\
\text { metered blood }\end{array}$ & $\begin{array}{l}44 \\
52 \\
31\end{array}$ & $\begin{array}{l}\text { Gas } \\
\text { Blood } \\
\text { ” }\end{array}$ & $\begin{array}{l}0.97 \\
0.79 \\
0.97\end{array}$ & $\begin{array}{r}-0 \cdot 2 \\
9 \cdot 1 \\
8 \cdot 3\end{array}$ & $\begin{array}{l}3 \cdot 2 \\
6 \cdot 1 \\
2 \cdot 2\end{array}$ \\
\hline \multicolumn{7}{|c|}{ B. Carbon dioxide electrodes (range 20-100 mm. $\mathrm{Hg}$ ) } \\
\hline $\begin{array}{l}\text { Radio- } \\
\text { meter }\end{array}$ & $\begin{array}{l}\text { Two gas mix- } \\
\text { tures }\end{array}$ & 48 & Blood & 1.04 & $-3 \cdot 2$ & $2 \cdot 4$ \\
\hline E5030 & $\begin{array}{l}\text { Tonometered } \\
\text { blood }\end{array}$ & 38 & " & 1.03 & $-2 \cdot 6$ & $1 \cdot 3$ \\
\hline I.L. $\mathrm{PCO}_{2}$ & $\begin{array}{l}\text { Two gas mix- } \\
\text { tures }\end{array}$ & 50 & " & 0.92 & $1 \cdot 1$ & $2 \cdot 4$ \\
\hline
\end{tabular}


For example, with the Radiometer $\mathrm{Po}_{2}$ electrode set up with nitrogen and air as reference points the equation is:

Electrode $\mathrm{Po}_{2}=7.4+0.90$ (tonometer gas $\mathrm{Po}_{2}$ ).

The constants $A$ and $B$ of these regression equations are shown in Table I. One standard deviation (S.D.) about the regression line (Bailey, 1959) is calculated for each equation, and this value is also shown in Table I. For each of the two $\mathrm{PO}_{2}$ electrodes calibration equations are calculated when nitrogen and moist air were used as the reference points, and also when nitrogen and blood tonometered with air were used as reference points.

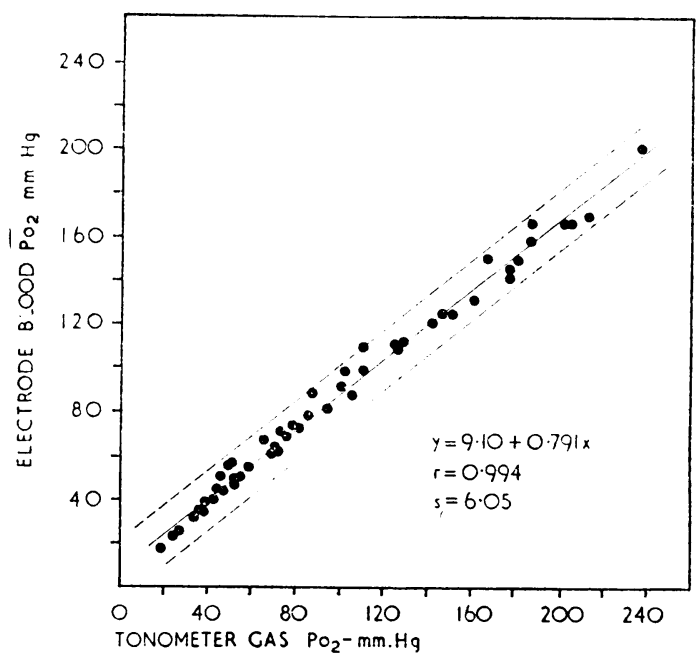

FIG. 2.-I.L. $\mathrm{PO}_{2}$ electrode, set up with nitrogen and moist air. Each point is the mean of two readings on each blood sample Broken lines at $95 \%$ confidence limits.

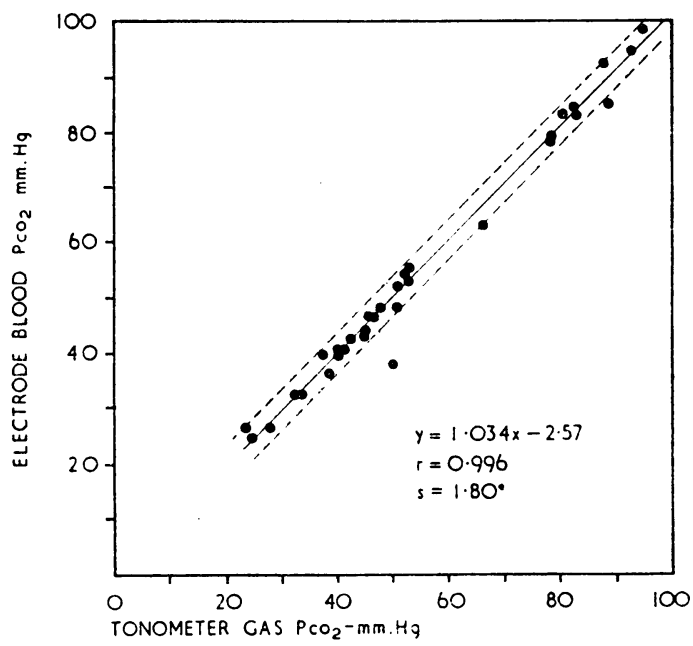

FIG. 3.-Radiometer $\mathrm{PCO}_{2}$ electrode, set up with tonometered blood. One reading on each blood sample. Broken lines at $95 \%$ confidence limits.

In addition, equations are also presented which describe the results when both oxygen electrodes were used to measure the $\mathrm{Po}_{2}$ of gas mixtures. Again, the constants $\mathrm{A}$ and $\mathrm{B}$ and one standard deviation are presented in Table $\mathrm{I}$. For the $\mathrm{PCO}_{2}$ electrodes the equations are based on gas mixtures as reference points, but, in addition, an equation is calculated for the Radiometer $\mathrm{PCO}_{2}$ electrode when blood samples which had been tonometred with two $\mathrm{CO}_{2}$ gas mixtures were used as the reference points.

Results are also presented in Figs. 5 and 6 for two experiments with the Radiometer electrode when the one operator carried out both $\mathrm{Po}_{2}$ and $\mathrm{PcO}_{2}$ measurements, and tonometry, at a rate of one fresh tonometric gas mixture every 25 minutes. This required rapid and skilled performance of numerous tasks.

\section{Discussion}

The difference between the reading of the electrodes and the $\mathrm{Po}_{2}$ (or $\mathrm{PcO}_{2}$ ) of the tonometer gas, which is regarded as the true reading, can be divided into two parts. The first, which is

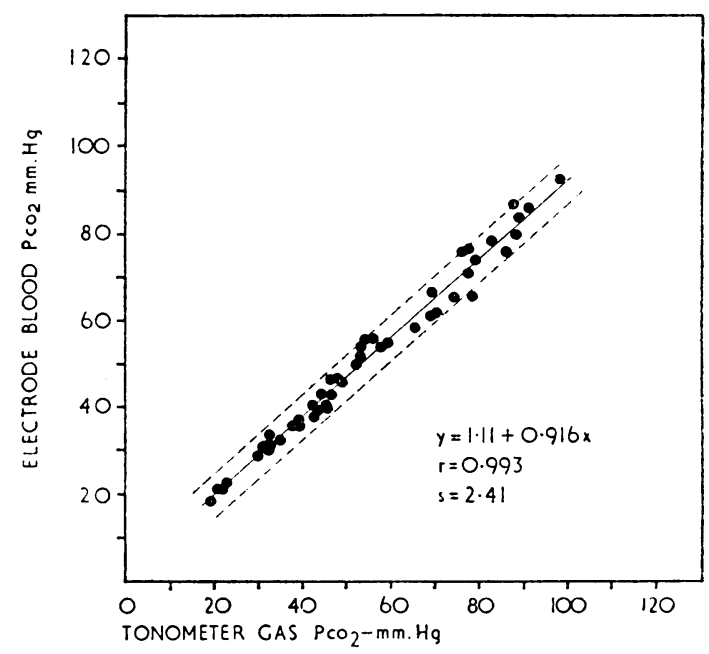

FIG. 4-I.L. $\mathrm{PCO}_{2}$ electrode, set up with gas mixtures. Each point is the mean of two readings on each blood sample. Broken lines at $95 \%$ confidence limits.

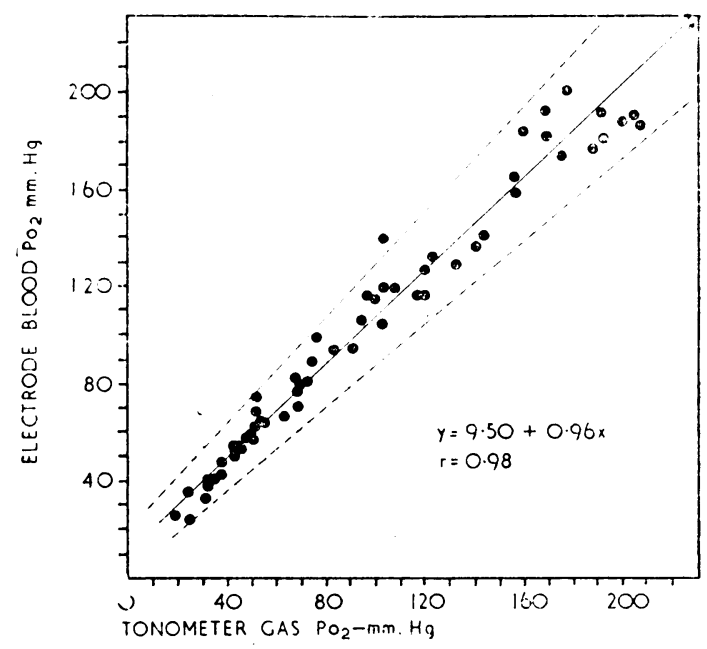

FIG. 5.-Radiometer $\mathrm{PO}_{2}$ electrode, set up with tonometered blood, under conditions of rapid use. One metered blood, under conditions of rapid use. $95 \%$

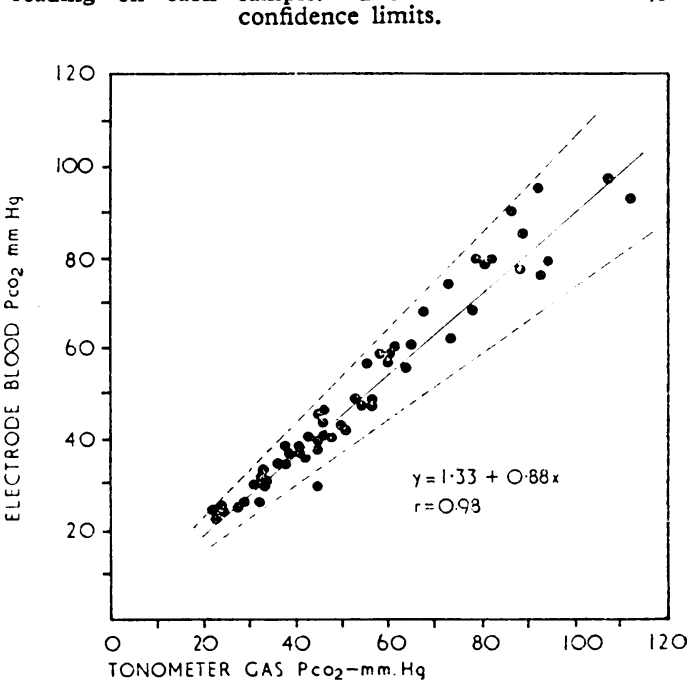

FrG. 6.-Radiometer $\mathrm{PCO}_{2}$ elcctrode, set 4 p with gas mixtures under conditions of rapid use. One reading on each sampls. Broken lines show $95 \%$ confidence limits. 
referred to as the systematic error, can be predicted from the coefficient and intercept of the regression equation shown in Table I. It therefore follows that such systematic errors can be eliminated by use of equations derived from these calibration graphs. It is commonly thought that the blood/gas ratio (the reading on blood divided by the reading on gas of the same $\mathrm{Po}_{2}$ ) is the only figure required to express the systematic error of a $\mathrm{PO}_{2}$ electrode. This ratio is not an adequate description of the systematic error of the electrode when used to measure the $\mathrm{Po}_{2}$ of blood in the range of $0-200 \mathrm{~mm}$. Hg considered here, for it assumes that the calibration graph passes through the origin. That this assumption is not valid is shown by the equations in Table I. The intercepts of the regression lines of the oxygen electrodes when used to measure the $\mathrm{Po}_{3}$ of gas mixtures are not significantly different from zero-that is, these lines pass through the origin-but the intercepts of the regression lines for blood $\mathrm{PO}_{2}$ do have a significant value. It follows that the only method of eliminating the systematic errors of these electrodes, when used to measure blood $\mathrm{PO}_{2}$ in this range, is to use calibration equations of the type described here. A similar intercept in the calibration graph for these electrodes is described by Moran et al. (1966). However, when the oxygen electrodes are used to measure the $\mathrm{Po}_{2}$ of gas mixtures these results indicate that a simple calibration with nitrogen and air is sufficient in this range to eliminate any systematic error.

The second part of the difference between the true reading and the electrode reading is the random error. This error is shown by the scatter, which can be expressed as the standard deviation about the regression line. For all practical purposes the $95 \%$ confidence limits of the regression are at \pm twice this standard deviation. The results with the Radiometer electrodes shown in Figs. 1, 3, 5, and 6 are on one reading only with each blood sample. The results with the I.L. instruments (Figs. 2 and 4) are based on the mean value of two readings. To make the Radiometer readings comparable, therefore, the standard deviation was divided by $\sqrt{ } 2$, and the results in this form are given in Table I.

The interaction of $\mathrm{CO}_{2}$ on the reading of the Radiometer oxygen electrode was determined in 60 experiments where the $\mathrm{PO}_{2}$ and the $\mathrm{PCO}_{2}$ were measured in both gas and tonometered blood. The multiple regression equation:

Electrode $\mathrm{Po}_{2}=7.27+0.95\left(\right.$ gas $\left.\mathrm{Po}_{2}\right)+0.07\left(\right.$ gas $\left.\mathrm{Pco}_{2}\right)$ shows no significant improvement in error over the simple equation:

which describes the same results.

Electrode $\mathrm{Po}_{2}=9.50+0.96\left(\right.$ gas $\mathrm{Po}_{2}$ ),

The $95 \%$ confidence limits of the electrodes at each of three levels of tonometer gas $\mathrm{Po}_{2}$ (or $\mathrm{PCO}_{2}$ ) are shown in Table II. These figures are obtained by substitution in the equations of Table I, and emphasize the total errors, both systematic and random, which would be encountered in practical use with these electrodes. The figures apply when the mean of two readings is taken as the "electrode $\mathrm{PO}_{2}$ (or $\left.\mathrm{PCO}_{2}\right)$." It will be apparent that the use of tonometered blood as the higher reference point for both $\mathrm{PO}_{2}$ electrodes reduces the systematic and random errors very considerably, and for the greatest accuracy this procedure appears imperative. We have no experience with the use of water equilibrated with air to set the high reference point (Bishop et al., 1967).

With the Radiometer $\mathrm{PCO}_{2}$ electrode we found that the use of blood tonometered with gas reduced the $95 \%$ confidence limits of the regression, but made no significant difference to the regression coefficient or intercept (Table I). The routine practice of calibrating these $\mathrm{PCO}_{2}$ electrodes with gas mixtures only will not, therefore, produce any systematic errors, but will increase the random errors. This may arise from the difficulty of preventing leakages of $\mathrm{CO}_{2}$ in delivery of the calibrating gases to the electrode, for, of course, this gas is much more diffusible than oxygen. The procedure we adopted of flushing the gas at $25 \mathrm{ml} . / \mathrm{min}$. through a short thick rubber tubing from a cylinder of compressed gas was that recommended by Severinghaus (1962).

TABLB II.-Measurements on Blood. $95 \%$ Confidence Limits of

\begin{tabular}{|c|c|c|c|c|}
\hline \multirow{2}{*}{ Electrode } & \multirow{2}{*}{$\begin{array}{c}\text { Reference } \\
\text { Points }\end{array}$} & \multirow{2}{*}{$\begin{array}{c}\text { True } \\
\text { Value } \\
\text { (mm. Hg) }\end{array}$} & \multicolumn{2}{|c|}{$95 \%$ Limits } \\
\hline & & & $\begin{array}{c}\text { Lower } \\
\text { (mm. Hg) }\end{array}$ & \begin{tabular}{|c} 
Upper \\
(mm. Hg)
\end{tabular} \\
\hline Radiometer $\mathrm{Po}_{2} \mathrm{E} 5044$ & Nitrogen. Air & $\begin{array}{r}40 \\
100 \\
200\end{array}$ & $\begin{array}{r}36 \\
90 \\
180\end{array}$ & $\begin{array}{r}51 \\
105 \\
195\end{array}$ \\
\hline Radiometer POa E5044 & $\begin{array}{l}\text { Nitrogen. Tono- } \\
\text { metered blood }\end{array}$ & $\begin{array}{r}40 \\
100 \\
200\end{array}$ & $\begin{array}{r}40 \\
98 \\
196\end{array}$ & $\begin{array}{r}50 \\
108 \\
206\end{array}$ \\
\hline Radiometer $\mathrm{PcO}_{2}$ E5030 & Two gas mixtures & $\begin{array}{r}30 \\
40 \\
100\end{array}$ & $\begin{array}{l}23 \\
34 \\
96\end{array}$ & $\begin{array}{r}33 \\
43 \\
106\end{array}$ \\
\hline Radiometer $\mathrm{PCO}_{2}$ E5030 & $\begin{array}{l}\text { Tonometered } \\
\text { blood }\end{array}$ & $\begin{array}{r}30 \\
40 \\
100\end{array}$ & $\begin{array}{l}26 \\
36 \\
98\end{array}$ & $\begin{array}{r}31 \\
41 \\
103\end{array}$ \\
\hline I.L. $\mathrm{Po}_{2}$ & Nitrogen. Air & $\begin{array}{r}40 \\
100 \\
200\end{array}$ & $\begin{array}{r}29 \\
76 \\
155\end{array}$ & $\begin{array}{r}53 \\
100 \\
179\end{array}$ \\
\hline I.L. $\mathrm{PO}_{2}$ & $\begin{array}{l}\text { Nitrogen. Tono- } \\
\text { metered blood }\end{array}$ & $\begin{array}{r}40 \\
100 \\
200\end{array}$ & $\begin{array}{r}43 \\
101 \\
198\end{array}$ & $\begin{array}{r}52 \\
110 \\
207\end{array}$ \\
\hline I.L. Pcos & Two gas mixtures & $\begin{array}{r}30 \\
40 \\
100\end{array}$ & $\begin{array}{l}24 \\
33 \\
88\end{array}$ & $\begin{array}{l}34 \\
43 \\
98\end{array}$ \\
\hline
\end{tabular}

The errors observed in this study must be compared with those found by others. The extensive work by Bishop et al. (1967) was carried out with his stirred macrocathode $\mathrm{Po}_{2}$ electrode, and suggests that this instrument may be intrinsically more accurate, for $95 \%$ confidence limits of $\pm 2.2 \mathrm{~mm}$. $\mathrm{Hg}$ in the range 0-150 mm. $\mathrm{Hg}$ were found. Nunn (1964) obtained an error proportional to the actual $\mathrm{Po}_{2}, 95 \%$ limits being $\pm 10.0 \mathrm{~mm}$. $\mathrm{Hg}$ at $100 \mathrm{~mm}$. $\mathrm{Hg}$. He also used a stirred macrocathode. Moran et al. (1966) calibrated I.L. and Radiometer unstirred microcathode electrodes, and report $95 \%$ confidence limits of $\pm 9.4 \mathrm{~mm}$. $\mathrm{Hg}$ for the I.L. electrode, and $\pm 5.0 \mathrm{~mm}$. $\mathrm{Hg}$ for the Radiometer electrode in the range 0-150 mm. $\mathrm{Hg}$. The regression equations reported by these authors are very similar to the present equations, but their studies included only three levels of tonometer gas below $105 \mathrm{~mm}$. Hg.

The accuracy of $\mathrm{PCO}_{2}$ electrodes has been little studied. Nunn (1964) again reported that the random error varied with the absolute level of $\mathrm{PCO}_{2}$, amounting to $95 \%$ limits of $\pm 4.0 \mathrm{~mm}$. $\mathrm{Hg}$ at $50 \mathrm{~mm}$. $\mathrm{Hg} \mathrm{PCO}$. Gambino (1961) reported $95 \%$ limits of $\pm 0.26 \mathrm{~mm}$. Hg, which are the errors of Haldane gas analysis alone, therefore leaving no error in the electrode or tonometer system, which appears remarkable.

Figs. 5 and 6 illustrate that the errors with both $\mathrm{Po}_{2}$ and $\mathrm{PCO}_{2}$ instruments will be very much greater when the operator is under considerable stress, no matter how familiar with the techniques. It would seem reasonable to suspect that the results obtained in actual practice may be more like these patterns than those in Figs. 1 to 4, which were obtained by the same operator.

\section{Summary}

The accuracy of the Radiometer $\mathrm{Po}_{2}$ electrode type E5044 and $\mathrm{PCO}_{2}$ electrode type E5030 and the Instrumentation Laboratories combined $\mathrm{PO}_{2}$ and $\mathrm{PCO}_{2}$ electrode system type 113-S1 for the determination of $\mathrm{Po}_{2}$ and $\mathrm{PCO}_{2}$ in blood is described. The assessment depended upon tonometry of blood with gas of known $\mathrm{Po}_{2}$ and $\mathrm{PcO}_{2}$ by means of a new tonometer. The errors of the measurements are systematic and random. Systematic errors can be eliminated by use of calibration graphs such as those described. Random errors can be reduced by using tonometered blood as reference points for both the $\mathrm{PO}_{2}$ and $\mathrm{PCO}_{2}$ electrodes. Examples of the total errors of these instruments are given. If the operator is skilled and the electrodes are calibrated with tonometered blood, he could measure $\mathrm{PCO}_{2}$ with an accuracy of + or $-3 \mathrm{~mm}$. $\mathrm{Hg}$ in the 
range 20-100 mm. $\mathrm{Hg}$ and $\mathrm{Po}_{2}$ with an accuracy of + or $-5 \mathrm{~mm} . \mathrm{Hg}$ in the range $0-200 \mathrm{~mm}$. $\mathrm{Hg}$. If the operator is less skilled and uses only gas calibration, the range of uncertainty doubles. The assessment was carried out over the range 0-200 mm. Hg for $\mathrm{PO}_{2}$ and $20-100 \mathrm{~mm}$. Hg for $\mathrm{PCO}_{2}$.

We wish to thank Professor K. W. Donald for advice and encouragement, Mr. W. Lutz for statistical advice, and Mr. J. A. Ramsay and Mrs. F. Burgess for skilled technical assistance. The tonometer was provided by the John Risk Bequest of Edinburgh University.
REFERENCES

Bailey, N. T. J. (1959). Statistical Methods in Biology. London. Bishop, J. M., Pincock, A. C., Hollybock, A., Raine, J., and Cole, R. B. (1967). Respir. Physiol., 1, 225.

Clark, L. C. (1956). Trans. Amer. Soc. artif. intern. Organs, 2, 41

Flenley, D. C. (1964). Quart. F. exp. Physiol., 49, 466.

and Millar, J. S. (1967). In preparation.

Moran, F., Kettel, L. J., and Cugell, D. W. (1966). F. appl. Physiol. 21, 725 .

Nunn, J. F. (1964). Brit. 7. Anaesth., 36, 327.

Severinghaus, J. W. (1962). Acta anaesth. scand., Suppl. No. 11 p. 207 and Bradley, A. F. (1958). 7. appl. Physiol., 13, 515.

\title{
Liquor Bilirubin Levels in Normal Pregnancy: A Basis for Accurate Prediction of Haemolytic Disease
}

\author{
E. D. MORRIS,* F.R.C.S., M.R.C.o.G.; JOHN MURRAY, † M.D., F.R.C.o.G., F.C.PATH. \\ C. R. J. RUTHVEN, $\ddagger$ M.SC., PH.D., F.R.I.C.
}

Brit. med. F., 1967, 2, 352-354

Amniocentesis has enjoyed ever-increasing popularity since Bevis (1956) related the absorption of the spectrophotometric curve at $450 \mathrm{~m} \mu$ with the prognosis of haemolytic disease of the newborn. In many countries estimation of liquor pigment levels has been preferred to maternal antibody titres as a guide for induction of labour (Walker, 1957 ; Cary, 1960 ; Freda, 1964); however, the general experience has been that the bile pigment level alone can be most misleading (Liley, 1963), particularly when specimens are contaminated with blood.

A number of wrong predictions were made at Queen Charlotte's Hospital in 1965 ; these included five Rh-negative babies which had been predicted as affected Rh-positive. At that time the only information available on the "normal" pigment level in liquor amnii was from $\mathrm{Rh}$-negative women with isoantibodies other than $\mathrm{Rh}$ who gave birth to normal babies or from Rh-isoimmunized women who gave birth to Rh-negative babies (Walker and Jennison, 1962 ; Walker et al., 1964 ; Watson et al., 1965).

Estimation was therefore made of pigment levels in liquor amnii in a series of normal Rh-positive pregnant women.

\section{Patients and Methods}

Liquor specimens from 29 Rh-positive normal pregnant women were examined during the 30 th to 32 nd weeks of gestation. These patients were all volunteers who were informed that the test was required purely for research purposes and was not part of their prenatal treatment. Specimens of liquor amnii were also taken from $22 \mathrm{Rh}$-negative mothers with histories of severe haemolytic disease and heterozygous husbands, or rising $\mathrm{Rh}$-antiglobulin antibody titre, or with an antibody titre that conflicted with a history of previous offspring with haemolytic disease or of stillbirths. In less severe cases the specimens were taken during the 28 th and 30th weeks of gestation, but in more severe cases likely to require intrauterine transfusion tests were made as early as the 20 th week.

About $10 \mathrm{ml}$. of liquor amnii was obtained by abdominal paracentesis, as described by Walker and Jennison (1962). The specimen was centrifuged, first in a clinical centrifuge to remove

\footnotetext{
* Resident Obstetrician.
+ Director of Pathology.

$¥$ Senior Biochemist.

Queen Charlotte's Maternity Hospital and Institute of Obstetrics and Gynaecology, London W.6.
}

any red cells, and then the supernatant was recentrifuged at 17,000 r.p.m. $(35,000 \mathrm{~g})$ in a refrigerated $\left(4^{\circ}\right.$ C.) centrifuge for 20 minutes to obtain a clear cell-free solution.

The optical extinction (E) of the clarified liquor was measured against water as a blank in a $1-\mathrm{cm}$. cuvette at $454,490,520$, and $574 \mathrm{~m} \mu$ with a Unicam S.P.500 spectrophotometer. The total bile pigment concentration in the specimen was determined by diazo-coupling, as described by Watson (1962), except that $1.4 \mathrm{ml}$. instead of $1 \mathrm{ml}$. liquor was taken for the test and the reagents were increased proportionally. The total protein concentration was determined by the biuret reaction: $0.5 \mathrm{ml}$. of liquor (or $0.25 \mathrm{ml}$. where the protein concentration was found to be greater than $5 \mathrm{mg}$. $/ \mathrm{ml}$.), diluted to $1 \mathrm{ml}$. with $0.9 \% \mathrm{w} / \mathrm{v}$ saline, was mixed with $1 \mathrm{ml}$. of biuret reagent, prepared by diluting stock reagent (Weichselbaum, 1946) one in five with $0.2 \mathrm{~N}$ sodium hydroxide containing $0.5 \% \mathrm{w} / \mathrm{v}$ potassium iodide. The intensity of the colour developing after standing for 15 minutes at $37^{\circ} \mathrm{C}$. was measured spectrophotometrically at $540 \mathrm{~m} \mu$. The protein concentration in the specimen was calculated by comparison with standards prepared from vacuumdried bovine albumin "Armour" treated with biuret reagent under the conditions of the test.

Cord and infant serum bilirubin estimations were carried out by the method of Lathe and Ruthven (1958). Group, Rh type, Coombs and albumin tests, and haemoglobin determination were made on cord blood. Mothers' blood was grouped and $\mathrm{Rh}$-typed, and the antibody titre was followed throughout pregnancy by means of the indirect Coombs test.

\section{Results}

The individual levels of protein concentration in liquor from $25 \mathrm{Rh}$-positive pregnancies, and bile pigment concentration in these cases, plus four similar ones, are shown in Table I, together with the observed differences in optical extinction $(\Delta \mathrm{E})$ between 454 and $574 \mathrm{~m} \mu$ and between 490 and $520 \mathrm{~m} \mu$, as described by Alvey (1964) and Knox et al. (1965) respectively. It should be emphasized that all optical readings were made in a cell of $1 \mathrm{~cm}$. light path, whereas Knox et al. (1965) used a light path of $0.5 \mathrm{~cm}$. Therefore our values of $\Delta \mathrm{E}(490-520 \mathrm{~m} \mu)$ are equivalent to twice those given by Knox et al. These results, apart from protein concentration, are summarized in Table II. They are classified in the respective ranges used for bilirubin 